\title{
O ritual do batismo em Portugal na Baixa Idade Média e nos inícios do século XVI
}

Francisca Pires de Almeida

\section{OpenEdition}

\section{Journals}

\section{Edição electrónica}

URL: http://journals.openedition.org/medievalista/1423

DOI: 10.4000/medievalista.1423

ISSN: 1646-740X

\section{Editora}

Instituto de Estudos Medievais - FCSH-UNL

Refêrencia eletrónica

Francisca Pires de Almeida, «O ritual do batismo em Portugal na Baixa Idade Média e nos inícios do século XVI », Medievalista [Online], 16 | 2014, posto online no dia 01 dezembro 2014, consultado no dia 30 abril 2019. URL : http://journals.openedition.org/medievalista/1423; DOI : 10.4000/ medievalista.1423 
Título: O ritual do batismo em Portugal na Baixa Idade Média e nos inícios do século XVI Autor(es): Francisca Pires de Almeida

Universidade: Universidade do Porto

Faculdade e Departamento / Unidade de Investigação: Faculdade de Letras da Universidade do Porto/ Departamento de Ciências e Técnicas do Património

Código Postal: 4150-564 Porto

Cidade: Porto

País: Portugal

Contacto: franciscadalmeida @gmail.com

Fonte: Medievalista [Em linha]. Direc. José Mattoso. Lisboa: IEM.

Disponível em: http://www2.fcsh.unl.pt/iem/medievalista/

ISSN: 1646-740X

Data recepção do artigo: 31 de Março de 2013

Data aceitação do artigo: 8 de Maio de 2014 


\section{Resumo}

O ritual do batismo infantil no período medieval e no século XVI ainda carece de atenção na historiografia portuguesa, apesar de para o seu estudo podermos dispor de um relevante conjunto de fontes documentais. É nossa intenção mostrar a importância que adquiriu no período medievo, a partir de ideias expressas pelo seu principal impulsionador, Santo Agostinho de Hipona, e a forma como evoluiu do ponto de vista ritual no virar do século XVI e depois das Reformas Protestantes.

Palavras-chave: batismo, neófitos, pecado original, ritual, Idade Média.

\section{Abstract}

The ritual of child baptism is still lacking attention in Portuguese historiography. In this article I will focus on its evolution during the Middle Ages, from the moment Saint Augustine of Hippo drew its foundations, until the sixteenth century and the pressure exerted by the Protestant Reformations on the Catholic Church.

Keywords: baptism, neophytes, original sin, ritual, Middle Ages. 


\title{
O ritual do batismo em Portugal na Baixa Idade Média e nos inícios do século XVI
}

\author{
Francisca Pires de Almeida
}

\section{Preâmbulo}

Habituamo-nos a ver o sacramento do batismo a ser administrado em crianças mas nem sempre foi assim. Não obstante a sua prática remontar ao século III, o primeiro sacramento recaiu sobretudo nos adultos que, depois de se prepararem como catecúmenos, pediam-no para ingressarem na Igreja e viverem como membros da comunidade cristã ${ }^{1}$. Só aos poucos é que o batismo infantil ganhou a atenção dos Padres da Igreja. Orígenes (c. 185-254), por exemplo, ofereceu justificações para a sua precoce administração, ao afirmar que limpava os pecados da nascença, como o pecado associado ao parto²; e São Cipriano (c. 205-258), como resposta à carta do bispo Fidus, sustentou que os neófitos não deveriam ser excluídos do sacramento e que, inclusive, o poderiam receber a partir do oitavo dia de nascimento. Todavia, foi Santo Agostinho (354-430) quem mais contribuiu para a sua difusão. Ao salientar, a partir da obra De peccatorum meritis, que sem o batismo as crianças não obtinham a salvação e a vida eterna, o bispo de Hipona deu um novo sentido e rumo ao primeiro sacramento ${ }^{3}$.

\footnotetext{
${ }^{1}$ ROUCHE, Michel - “O corpo e o coração". in ARIÈS, Philippe; DUBY, Georges - História da Vida Privada: Da Europa Feudal ao Renascimento. Porto: Edições Afrontamento, 1990, p. 439.

${ }^{2}$ FERGUSON, Everett - Baptism in the Early Church: History, Theology, and Liturgy in the First Five Centuries. Michigan: Wm. B. Eerdmans Publishing, 2009, pp. 367-369.

${ }^{3}$ BAREILlE, G. - "Baptême". in VACANT, A.; E. MANGENOT; É. AMANN, (eds.) - Dictionnaire de Théologie Catholique contenant l'exposé des doctrines de la théologie catholique leurs preuves et leur histoire. Tomo II. Paris: Librairie Letouzey et Ané, 1932, p. 194.
}

Medievalista online № 16। Julho - De ze mbro 2014 ( ) $\mathbb{E M}$ - Instituto de Estudos Me dievais 3 www2.fc sh.unl.pt/ ie $\mathrm{m} / \mathrm{me}$ die va lista 
Para se distinguir do batismo dos adultos, o batismo infantil acolheu novos elementos na sua celebração. Introduziram-se os exorcismos para salvar a alma conspurcada da criança e recorreu-se à ajuda dos adultos para que respondessem em nome do bebé às questões do sacerdote, alterando-se a formulação das respostas da $1^{\text {a }}$ para a $3^{\text {a }}$ pessoa do singular. Por exemplo, quando o ministro colocava a questão “Acredita [o neófito] em Jesus Cristo?", os padrinhos respondiam "Ele acredita"4.

Lançadas as primeiras bases para uma nova cerimónia batismal, o sacramento seguiu os preceitos de um ritual de passagem já que incluía as três fases propostas por Arnold Van Gennep: separação, liminar e agregação5. Edward Muir distingue-as claramente no batismo do Antigo Regime. Segundo o historiador, o rito de separação iniciava-se com os exorcismos realizados na porta da igreja para afastar o reino de Satanás através da bênção de Deus. A segunda fase acontecia quando a criança era retirada dos braços de quem a transportava e era levada até ao batistério para ser submersa na água da fonte batismal. E, na fase final, a da agregação, o sacerdote colocava a criança nos braços dos padrinhos para a incorporar na comunidade cristã ${ }^{6}$.

Embora seja difícil datar com precisão quando é que se deu a generalização do batismo infantil, o certo é que no século VIII já era administrado no primeiro ano de vida do bebé durante o período pascal ${ }^{7}$; e, para o território que um dia viria a ser Portugal, podemos afirmar que já aí se praticava desde o século VI. Assim o demonstra o $7^{\circ}$ artigo do Segundo Concílio de Braga, celebrado em 572 e presidido por S. Martinho de Dume, que determinou que nada se deveria pedir aos pais das crianças para administrar o primeiro sacramento, aceitando-se apenas dádivas voluntárias ${ }^{8}$.

A par do êxito do batismo infantil, o próprio ritual foi-se moldando ao longo dos séculos mas de forma diferenciada de reino para reino ou até de região para região e, foi

\footnotetext{
${ }^{4}$ FERGUSON, Everett - Baptism in the Early Church..., cit., p. 788-789.

${ }^{5}$ GENNEP, Arnold Van - Os ritos de passagem. Petropolis: Vozes, 1978, p. 31-32.

${ }^{6}$ Edward Muir distinguiu essas três fases no batismo durante o período moderno mas, no nosso entender, elas são igualmente aplicáveis ao batismo no período medieval. MUIR, Edward - Fiesta y rito en la Europa Moderna. Madrid: Editorial Complutense, 2001, p. 14-15.

${ }^{7}$ RUBELLIN, Michel - "Baptême". in VAUCHEZ, André (dir.) - Dictionnaire Encyclopédique du Moyen Âge: Tome I. Paris: Éditions du Cherf, 1997, p. 171.

${ }^{8}$ SOARES, António Franquelim Sampaio Neiva - "Os Concílios Suevos (561 e 571)". in KOLLER, Erwin; LAITENBERGER, Hugo (ed.) - Suevos -Swaben: Das Konigreich der Sueben auf der Iberischen Halbinsel (411-585). Tübingen: Gunter Narr Verlag, 1998, pp. 74-76.
}

Medievalista online № 16 । Julho - De ze mbro $2014 \odot \mathbb{E}$ (Instituto de Estudos Medie va is 4 www2.fc sh.unl.pt/ie m/me die va lista 
apenas durante o pontificado de Paulo V que fixou os seus elementos fundamentais, consignados no Ritual Romano de 1614. Este foi adotado em Portugal, embora não se tenha imposto como obrigatório, permitindo a coexistência de outros manuais que mantiveram as suas tradições ${ }^{9}$. Assim, não é de estranhar que tenham surgido em Portugal manuais litúrgicos como os de Braga (1517), Coimbra (1518) e Évora (1528), que manifestaram, também neste domínio, os seus próprios particularismos ${ }^{10}$. Ainda que do século XVI, estes manuais demonstraram continuidades face a uma tradição medieval que remonta ao século XII, como adiante veremos ${ }^{11}$.

\section{O ritual do batismo: confluência ou divergência?}

Foi no âmbito da reforma gregoriana que, durante os finais do século XI e princípios do século XII, o território português de entre Mondego e Minho substituiu a liturgia hispânica em favor da romana ${ }^{12}$. Acontece que a concretização da reforma litúrgica por intermédio de livros oriundos de França e com conteúdos galicanos deu origem à liturgia bracarense que, por sua vez, conduziu à emancipação da liturgia conimbricense e eborense. Assim, embora estas dioceses adotem os modos de batizar romanizados (imersão, colocação da mão e do sal, por exemplo), os três manuais testemunham a influência do batismo galicano no que diz respeito às preces exuberantes e à enfase de gestos simbólicos presentes em grande parte no Missal de Mateus que, tal

\footnotetext{
9 PEIXOTO, João da Silva - "Liturgia". in AZEVEDO, Carlos Moreira (dir.) - Dicionário de História Religiosa de Portugal: J-P. Rio de Mouro: Círculo de Leitores, 2001, p. 141.

10 Relativamente ao manual de Braga demos sobretudo atenção à edição de 1517, mas houve uma impressão anterior, de 1496. Ver CARVALHO, Joaquim Félix de - “A Liturgia em Braga”. Didaskalia. Lisboa ISSN 0253-1674. 37:2 (2007), p. 156.

${ }^{11}$ É preciso ter em atenção que a introdução da imprensa contribuiu para uma multiplicação dos textos litúrgicos, cujos primeiros exemplares impressos conhecidos datam do tempo do arcebispado de Braga de D. Jorge da Costa (1486-1501/1505). As fontes manuscritas, em contrapartida, deterioraram-se com o tempo e com o uso; por isso, concentrámos a nossa atenção no ritual do batismo tal como está documentado em manuais litúrgicos dos princípios do século XVI. (Ver. MARQUES, João Francisco “A palavra e o livro". in AZEVEDO, Carlos Moreira (dir.) - História Religiosa de Portugal. Volume 2: Humanismo e Reformas. Rio de Mouro: Círculo de Leitores, 2000, p. 426-428).

12 PEIXOTO, João da Silva - "Rito". in AZEVEDO, Carlos Moreira (dir.) - Dicionário de História Religiosa de Portugal: P-V. Rio de Mouro: Círculo de Leitores, 2001, p. 132.
}

Medievalista online № 16। Julho - De ze mbro 2014 ( ) $\mathbb{E M}$ - Instituto de Estudos Me dievais 5 www2.fc sh.unl.pt/ ie $\mathrm{m} / \mathrm{me}$ die va lista 
como os restantes livros litúrgicos franceses, chegou à Península Ibérica no século XII ${ }^{13}$.

Detenhamo-nos primeiramente sobre os manuais de Braga (1517) e de Coimbra (1518), cuja análise revelou notórias semelhanças entre ambos. Seguindo com atenção os dois manuais, apercebemo-nos que a celebração do batismo incluía as três fases de um ritual de passagem:

1) A primeira etapa ocorria do lado de fora da porta principal da igreja, onde o sacerdote perguntava aos padrinhos qual o nome a dar à criança. Depois de nomeada, dava-se então começo aos vários exorcismos. Em primeiro lugar, realizavam-se na face do bebé as três insuflações, que assumiam a forma de uma cruz, com o propósito de afastar o diabo ${ }^{14}$. Após os sopros, seguiam-se os sinais da cruz estendidos às várias partes do corpo: nos olhos para que visse Deus; nos ouvidos para o ouvir; nas narinas para que usufruísse o seu odor; no peito, ou melhor, no coração, para que nele acreditasse; e na boca para o demonstrar através das suas palavras ${ }^{15}$. Depois, o sacerdote colocava a mão direita sobre a cabeça do pequeno para destruir os laços que o prendiam a Satanás. Passava-se então à administração do sal, depois de o exorcizar ${ }^{16}$. Segundo Nicolas Lopez Martinez, as liturgias apelavam aos méritos divinos para purificar os elementos sacramentais e os afastar do domínio do demónio ${ }^{17}$. Por isso, os manuais de

13 BRAGANÇA, Joaquim de Oliveira - "Influência religiosa da França no Portugal Medievo". Didaskalia. Lisboa. ISSN 0253-1674. 3:1 (1973), p. 149.

14 As três insuflações provêm do costume romano cuja prática já se incluía na liturgia hispânica. BRAGANÇA, Joaquim O. - "Le symbolisme des rites baptismaux au Moyen Age: les rites d'admission au catéchuménat”. Didaskalia. Lisboa. ISSN 0253-1674. 3:1 (1973), p. 44.

${ }^{15}$ Neste breue manual se [con]ten cousas muito necessarias e p[ro]ueitosas a todo sacerdote q[ue] ha de administrar e dar os sacrame[n]tos...E assi som muitas missas deuotissimas e p[ro]ueitosas p[e]ra ha saude dalma e do corpo. as quaes nu[n]ca foro[m] postas em nenhu[m] missal ne[m] manual de Braga (doravante Manual de Braga). Impressus in antiquissima bracharensis civitate: [s.n.], 1517, fl. 2-2v.; Manuale secundu[m] consuetudinem alme Colymbrieñ [sic] Ecclesie (doravante Manual de Coimbra). Lixboneñ ciuitate: Nicolaum Gazini, 1518, fl. 2.

${ }^{16}$ A colocação do sal já vinha do tempo de Santo Agostinho e foi aceite por todas as tradições das igrejas locais. Apenas divergia a oração do exorcismo. O ritual romano optava por Benedicto salis enquanto que outros rituais, como o galicano, davam preferência ao Exorcismus salis. BRAGANÇA, Joaquim O. - Le symbolisme..., cit., p. 53.

${ }^{17}$ LOPEZ MARTINEZ, Nicolas - "Notas sobre la lucha contra el diablo mediante los sacramentos". in $I V$ SIMPÓSIO INTERNACIONAL DE TEOLOGÍA DE LA UNIVERSIDAD DE NAVARRA, Pamplona,

Medievalista online № 16 । Julho - De ze mbro 2014 ( $\mathbb{E M}$ - Instituto de Estudos Me dieva is 6 www2.fc sh.unl.pt/ ie m/me die va lista 
Braga e de Coimbra exigiam o exorcismo do sal, pedindo ao Criador que o transformasse num medicamento perfeito (perfecta medicina) para afugentar o inimigo. Daí que fosse colocado na boca do recém-nascido ${ }^{18}$. Entre as orações que se seguiam, intercaladas com mais dois sinais da cruz na testa, finalizava-se a primeira ronda dos exorcismos com abjurações para amaldiçoar o diabo. Para ultimar a primeira fase do ritual, o sacerdote orava com os padrinhos o Credo in Deum, o Pater Noster e o Ave Maria.

2) Ao deixarem o adro da igreja, dava-se lugar à fase liminar, que já ocorria dentro desta. O manual de Braga exortava a que o sacerdote abrisse com a sua saliva os sentidos, isto é, as narinas e os ouvidos do recém-nascido com duas intenções: expulsar o diabo e tornar a criança capaz de ouvir e sentir o odor de Deus ${ }^{19}$. Depois, seguido pelos padrinhos, levava a criança nos braços para junto da pia batismal, enquanto entoava a ladainha de Todos os Santos e o Kyrie eleison ${ }^{20}$. Aí, benzia e exorcizava a fonte. Ambos os manuais impunham que o sacerdote revolvesse duas vezes sob a forma de cruz a água batismal, lançando-a de seguida para fora do bacio. Aconselhavam também a que o ministro alterasse o seu tom de voz, "asi como quando lee la leçom", soprasse sobre a água em forma de cruz e lhe inserisse um círio aceso. E, por fim, recomendavam que nela derramasse o óleo do crisma e o óleo santo de per se e só depois os dois conjuntamente. Desta forma, a água batismal adquiria o poder de santificar: lavaria os vícios (pecado original) e regeneraria para se exercer o bem ${ }^{21}$. Dirigindo novamente a atenção para o bebé, o ministro retirava-lhe a roupa e passava às renunciações a Satanás e às suas obras e pompas, às quais os padrinhos respondiam Abrenuncio. Colocava, sob a forma de cruz, o óleo dos catecúmenos entre as espáduas e o peito do menino para que adquirisse vida eterna e, voltava a interrogar os padrinhos sobre os artigos da fé, questionando-os por três vezes se era intenção da criança ser batizada. Os padrinhos respondiam afirmativamente enquanto a tocavam. Deste modo,

1983 - Sacramentalidad de la Iglesia y Sacramentos: actas. Pamplona: Servicio de Publicaciones de la Universidad de Navarra, 1983, p. 807.

${ }^{18}$ Manual de Braga, fl. 2v.; Manual de Coimbra, fl. 2v.

19 O manual de Coimbra não exclui a abertura dos sentidos, apenas altera a ordem, impondo a administração da saliva após o exorcismo da fonte batismal e antes das renunciações (Cf. Manual de Coimbra, fl. 6v.); Manual de Braga, fl. 4v.

${ }^{20}$ A ordem de invocação dos santos e arcanjos variou.

${ }^{21}$ Manual de Braga, fl. 6-7; Manual de Coimbra, fl. 4v.-6v.

Medievalista online № 16 । Julho - De ze mbro $2014 \odot \mathbb{E M}$ - Instituto de Estudos Me die va is 7 www2.fc sh.unl.pt/ie m/me die va lista 
ficava pronta para ser banhada por três vezes na fonte batismal com a fórmula Ego te baptizo in nomine patris et filii et spiritus sancti ${ }^{22}$.

3) Assim que emergia da água batismal, dava-se a fase de agregação. O padre fazia-lhe na cabeça o sinal da cruz com o óleo do crisma, salientando que tinha sido regenerada pela graça do Espírito Santo. Colocava-lhe o "capelo" branco para que um dia fosse levada ao tribunal do Senhor e entregava-lhe a vela acesa na mão direita para que Cristo a encontrasse na sala da justiça celestial. Despedia-se dos padrinhos e advertia-os para que ensinassem a fé ao afilhado ${ }^{23}$. Dava-se assim por concluído o ritual do batismo.

Não obstante a publicação do manual de Évora (1528) ser mais tardia do que a dos de Braga e Coimbra, demonstra que seguiu mais fielmente o ritual do batismo do Missal de Mateus $^{24}$. No que ao batismo diz respeito, mesmo sendo o manual de Évora bastante semelhante aos manuais de Braga e Coimbra, foi-nos possível detetar diferenças ${ }^{25}$.

Vejamos a primeira fase do ritual. Enquanto que os manuais de Braga e Coimbra apenas aludiam ao exorcismo do sal, Évora acrescentava ao exorcismo uma bênção Benedic omnipotens deus hanc creaturam salis - como exigia o Missal de Mateus ${ }^{26}$. E, logo após a colocação do sal, era requerido um simples sinal da cruz na testa da criança, ao passo que em Braga e Coimbra se requeriam dois sinais intercalados entre as orações $^{27}$. Na transição do rito de separação para a fase liminar e, seguindo mais uma vez o Missal de Mateus, o manual de Évora apresentava um outro panorama. Impunha ao sacerdote que, antes de entrar na igreja, colocasse a mão direita sobre a criança e que

\footnotetext{
${ }^{22}$ Apenas ficam dúvidas se Braga optou por uma imersão, uma vez que não alude à sub trina mersione. Manual de Braga, fl. 7; Manual de Coimbra, fl. 7.

${ }^{23}$ Manual de Braga, fl. 7; Manual de Coimbra, fl. 7.

${ }^{24}$ Para o Missal de Mateus seguimos na íntegra a transcrição de Joaquim O. Bragança - Missal de Mateus: manuscrito 1000 da Biblioteca Pública e Arquivo Distrital de Braga (doravante Missal de Mateus). Lisboa: Fundação Calouste Gulbenkian, 1975.

${ }^{25}$ No microfilme do Manual de Évora de 1528 (ex. da Biblioteca Nacional de Portugal [Cota: F. 197]) está ausente o fólio 2 correspondente à cerimónia do batismo, pelo que não podemos proceder à comparação das insuflações e do sinal da cruz, aplicado nos 5 sentidos.

${ }^{26}$ Baptisteriu[m] seu manuale Elborense noviter eme(n]datus (doravante Manual de Évora). Hispali: per Jacobum Cromberger, 1528, fl. 3v.; Missal de Mateus, fl. 113v.

${ }^{27}$ Évora continua a seguir passo a passo o Missal de Mateus. Manual de Évora fl. 4v.; Missal de Mateus, fl. $113 \mathrm{v}$.
}

Medievalista online № 16 । Julho - De ze mbro $2014 \odot \mathbb{E}$ (Instituto de Estudos Medie va is 8 www2.fc sh.unl.pt/ie m/me die va lista 
proferisse o Pater Noster e o Credo in Deum, substituindo o Ave Maria por uma pequena oração para que a bênção de Deus alcançasse o pequeno e o levasse à vida eterna; ao não mencionar os padrinhos, o manual de Évora dá a entender que não acompanhavam o sacerdote nestas orações ${ }^{28}$.

A segunda fase da celebração também registava algumas diferenças. É no manual de Évora (e também no Missal de Mateus) que entendemos particularmente como se efetuava a abertura dos sentidos. A intenção era a mesma que em Braga e Coimbra, não se descurando a saliva para tal efeito. Contudo, o manual de Évora realçava particularmente a orelha esquerda; ao murmurar-lhe, o diabo fugiria e os restantes orifícios destapar-se-iam para Deus ${ }^{29}$. Outro aspeto a assinalar era a forma como em Évora se exorcizava a pia batismal. Distanciando-se desta vez da sua fonte de inspiração, isto é, do Missal de Mateus e, por conseguinte, também dos manuais das dioceses de Braga e Coimbra que, neste aspeto, seguiam com mais rigor a fonte francesa, Évora optou em alguns momentos por outro rumo. Ao invés das duas dioceses referidas, cujos rituais determinavam que o sacerdote revolvesse a água batismal por duas vezes, Évora alargou para três o número de revolvimentos, decretando que depois fosse marcada com três cruzes. Não obstante as três corresponderem ao momento em que se aconselhava que o ministro mudasse o tom de voz, soprasse sobre a água e nela inserisse um círio aceso, as determinações do manual de Évora voltavam a demarcar-se no momento da colocação dos óleos; Évora apenas prescrevia que se deitasse o óleo do crisma na água batismal ${ }^{30}$.

Só na terceira etapa da celebração é que os três manuais (assim como o Missal de Mateus) voltam a ser semelhantes entre si. Uma outra semelhança visível nas quatro fontes às quais temos vindo a dar atenção é o ritual do batismo dos "mininos" e das "mininas". Idêntico para os dois sexos, nenhum manual apresentou alguma

\footnotetext{
${ }^{28}$ Manual de Évora, fl. 6v.-7; Missal de Mateus, fl. 14v.

29 Desde o período medieval que o lado direito simbolizava o "bem" e o lado esquerdo o "mal". O princípio bipolar direita-esquerda teve a sua origem nas narrativas do Novo Testamento como por exemplo na passagem do Juízo Final ("E colocará as ovelhas à sua direita e os cabritos à sua esquerda." Mateus 25:33). Ver SCHLEIF, Corine - "Men on the Right - Women on the Left: (A)symetrical Spaces and Gendered Places". in RAGUIN, Virginia C.; STANBURY, Sarah (eds.) - Women's Space. Patronage, Place, and Gender in the Medieval Church. Albany: State University of New York Press, 2005, p. 213.; Manual de Évora, fl. 7v.; Missal de Mateus, fl. 14v.

${ }^{30}$ Manual de Évora, fl. 8v-11.
}

Medievalista online № 16 । Julho - De ze mbro 2014 @ $\mathbb{E M}$ - Instituto de Estudos Medieva is 9 www2.fc sh.unl.pt/ ie m/me die va lista 
manifestação de desigualdade, quer nas orações quer nos gestos inerentes à administração deste sacramento. Sandy Bardsley notou que havia uma diferença de tratamento na cerimónia do batismo medieval no momento em que o sacerdote colocava os bebés do sexo masculino do seu lado direito (considerado o lado sagrado e importante) e os do sexo feminino do seu lado esquerdo ${ }^{31}$. No caso dos referidos manuais portugueses, a única diferença que o manual de Braga estabelece no que toca ao modo de batizar dos dois sexos é evitar um engano discursivo; assim, no título desse manual encontramos a seguinte explicação: "Neste breue manual [...] se contem dous baptismos huum pera ho macho et outro pera ha femea cada huum de per se [...] de maneira que nenhum sacerdote pode errar no mudar do latim"32; ou seja, o que estava em causa era garantir a validade do sacramento, diferenciando entre rapazes e raparigas no texto proferido pelo padre.

Em suma, a confrontação das prescrições relativas à cerimónia batismal nos referidos três costumes vem apenas provar que, ainda em pleno século XVI, se seguia uma fonte medieval. Braga e Coimbra de uma forma mais frugal e Évora de uma forma mais evidente. No entanto, sabemos que uma edição do manual bracarense, impressa em 1496, reproduziu na íntegra o Missal de Mateus no que ao batismo dizia respeito, suprimindo apenas duas orações da fonte galicana que, por repetidas, foram dispensadas $^{33}$. E se o manual bracarense de 1496 exerceu influência noutras dioceses como as do Porto ou Viseu, quem sabe se o ritual do batismo segundo o Missal de Mateus não foi celebrado de forma semelhante noutras dioceses do reino ${ }^{34}$ ?

\footnotetext{
${ }^{31}$ Encontramos essa distinção de tratamento para o período moderno nomeadamente na edição portuguesa do Ritual Romano paulino, impresso por Pedro Craesbeeck, em 1617. BARDSLEY, Sandy - Women's Roles in the Middle Ages. Portsmouth: Greenwood Press, 2007, p. 92.

${ }^{32}$ Neste breue manual se [con]ten cousas muito necessarias e p[ro]ueitosas a todo sacerdote q[ue] ha de administrar e dar os sacrame[n]tos...E assi som muitas missas deuotissimas e p[ro]ueitosas p[e]ra ha saude dalma e do corpo. as quaes nu[n]ca foro[m] postas em nenhu[m] missal ne [m] manual de Braga. Impressus in antiquissima bracharensis civitate: [s.n.], 1517.

${ }^{33}$ BRAGANÇA, Joaquim O. - "A Liturgia de Braga: Missal - Ritual - Pontificial". in CONGRESSO INTERNACIONAL DO IX CENTENÁRIO DA DEDICAÇÃO DA SÉ DE BRAGA, 3, Braga, 1990 Teologia do Templo e Liturgia Bracarense: actas. Braga: Universidade Católica Portuguesa, 1990, p. 125. ${ }^{34}$ GOMES, Saul António - "A religião dos clérigos: vivências espirituais, elaboração doutrinal e transmissão cultural”. in AZEVEDO, Carlos Moreira (dir.) - História Religiosa de Portugal. Vol. 1: Formação e Limites da Cristandade. Rio de Mouro: Círculo de Leitores, 2000, p. 355.
} 
Se foi o caso, então foi apenas na segunda metade do século XVI que o Missal de Mateus ganhou concorrência com a chegada dos bautistérios, que propuseram novas formas rituais ${ }^{35}$. No nosso entender, o Bautisteiro romão editado por Germão Galharde em 1560 revela sinais evidentes de tendência reformista: diminuiu o número de insuflações para uma, limitou o sinal da cruz para uma singela aplicação no peito e testa, omitiu a ladainha, e reduziu os exorcismos da pia batismal (revolvimentos, círio, etc.) a um mero derramamento do óleo do crisma na água batismal ${ }^{36}$. Houve, neste Bautisteiro, uma intenção de simplificar toda a gestualidade associada ao ritual do batismo, talvez para resguardar o sacramento das críticas protestantes, como luteranas e calvinistas, que acusavam a Igreja romana de conferir ao batismo uma força "mágica"37. Aparentemente, a consciência do período moderno distanciou-se das exigências da sociedade medieval que repousavam em grande medida no poder do gesto o que, segundo Jacques Le Goff, caracterizava em larga medida a civilização medieval ${ }^{38}$.

\section{Regulamentação eclesiástica portuguesa}

Paralelamente aos manuais litúrgicos que, como vimos, guiaram e moldaram a celebração do batismo, existiam as constituições diocesanas para regularem e disciplinarem o primeiro sacramento. Estes instrumentos normativos dedicaram um capítulo específico ao batismo, onde impunham uma série de cânones de cariz mais taxativo e com informações adicionais para servirem de suplemento à liturgia e auxiliarem os sacerdotes nas questões práticas. O seu conteúdo permitiu-nos avaliar temporalmente a importância que conferiram ao primeiro sacramento e a forma como reforçaram a sua administração. Assim, balizaram os dias para a celebração do batismo, limitaram o número e a escolha de padrinhos e, por vezes, mencionaram os batizados dos filhos dos clérigos.

Conquanto que a celebração do batismo a todos os recém-nascidos (quamprimum) se tenha tornado numa prática generalizada no Ocidente no século XIII, foi por influência do Concílio de Florença (1439-1445) que as constituições sinodais

\footnotetext{
${ }^{35}$ Os bautistérios surgem a partir de 1548 (PEIXOTO, João da Silva - Liturgia..., cit., pp. 141-142).

${ }^{36}$ Bautisteiro romão cõ algu[m] as outras cousas necessarias aos curas e capellães e cõ as rubricas em lingoage [m] conforme ao mais geral uso de MDLX. Lisboa: Germão Galharde, 1560.

${ }^{37}$ DELUMEAU, Jean - Nascimento e Afirmação da Reforma. São Paulo: Livraria Pioneira Editora, 1989, pp. 93, 131-132.

${ }^{38}$ LE GOFF, Jacques - La civilisation de L'Occident Médiéval. Paris: Arthaud, 1977, p. 440.
} 
portuguesas da segunda metade do século XV passaram a recomendar a administração do sacramente entre o nascimento do bebé e o seu oitavo dia de vida, uma vez que Cristo havia sido circuncidado aos oito dias ${ }^{39}$. Segundo D. Diogo Ortiz de Vilhegas (c. 1454-1519), era no tempo do Senhor que pela "circumcisam perdoava Deos o pecado original" 40 . Mesmo assim, havia pais que não cumpriam este prazo, pondo em causa a salvação dos seus filhos, como destaca o arcebispo de Braga, D. Luís Pires: “[...] polla negligencia de muitos padres e madres e ainda por sua ponpa, por tomarem mais padrinhos e madrinhas dos que o direito manda ou por aguardarem alguuns que venham de fora pera os tomarem por conpadres, muitas vezes acontece muitas criaturas morrerem sem bautismo e serem dapnados nom por culpa sua, mas por culpa dos mezquinhos padres e madres" 41 . Por conseguinte, o prazo dos oito dias continuou bem patente nas constituições de transição ${ }^{42}$; apenas Braga concedeu um limite de $9 \operatorname{dias}^{43}$.

As constituições sinodais também demonstram que no século XIII já existia uma restrição para a nomeação dos padrinhos. Não podiam ser mais de três, homens ou mulheres, nem contrair matrimónio entre si, regra que, na parte que ao matrimónio dizia respeito, nem sempre seria observada na arquidiocese de Braga, como testemunha a constituição do arcebispo D. Frei Telo ${ }^{44}$. Mas o desejo de limitar os pais quanto à escolha dos padrinhos não ficou por aqui. À medida que o tempo avançou, as

\footnotetext{
${ }^{39}$ Daremos um maior destaque às constituições das últimas décadas do século XV e primeira metade do século XVI, porque correspondem a um período de mudanças na Igreja portuguesa. Menos citadas foram as constituições sinodais do século XIII, por tratarem levemente a questão do batismo, já que estavam mais interessadas em regular os costumes dos clérigos e a adequada gestão dos bens da Igreja. PAIVA, José Pedro - "Constituições Diocesanas”. in AZEVEDO, Carlos Moreira (dir.) - Dicionário de História Religiosa de Portugal: C-I. Rio de Mouro: Círculo de Leitores, 2000, pp. 12-13.; Ver também RUBELLIN, Michel - Baptême...., cit., p. 171; WALSH, Liam G. - Sacraments of Initiation: A Theology of Right, Word and Rite. Chicago: Hillenbrand Books, 2011, p. 139.

${ }^{40}$ SILVA, Elsa Maria Branco da - O Cathecismo Pequeno de D. Diogo Ortiz: Bispo de Viseu. Lisboa: Colibri, 2001, p. 141.

41 “Constituições Sinodais de D. Luís Pires, Braga, 11 Dez.1477”. in GARCIA Y GARCIA, Antonio (dir.) - Synodicon Hispanum: Vol.2, Portugal. Madrid: Editorial Católica, 1982, pp. 102-103.

42 Constituições "de transição", assim por nós designadas porque dizem respeito à primeira metade de Quinhentos, encontrando-se num período de charneira entre a Idade Média e a Idade Moderna e, por conseguinte, contemporâneas dos manuais anteriormente aqui tratados.

${ }^{43}$ Constituições do arcebispado de Braga. Lisboa: Germã Galharde, 1538, fl. 1.

44 “Constituições Sinodais de D. Frei Telo, Braga, 1285”. in GARCIA Y GARCIA, Antonio (dir.) Synodicon Hispanum..., cit., p. 27.
}

Medievalista online № 16। Julho - De zembro 2014 (C) EM - Instituto de Estudos Medieva is 12 www2.fc sh.unl.pt/ie m/me die va lista 
constituições sinodais tornaram-se mais rígidas. Independentemente de algumas constituições da segunda metade do século XV darem continuidade à tradição, como foi o caso das de Braga de 1477 ou de Valença do Minho de 1486, houve outras que se pautaram pela mudança, apelando para uma renovação. Assim acontece nas constituições do Porto de D. Diogo de Sousa (1496), que estabelecem como norma um padrinho e uma madrinha para cada criança. Já as constituições de transição vão apelar a que o padrinho não tenha menos de catorze anos e a madrinha menos de doze, sendo que ambos teriam de ser batizados e crismados. Da mesma forma, excluíam padrinhos do clero regular, assim como mudos, excomungados e casais ${ }^{45}$. No entanto, o seu número continuava a variar: havia dioceses que apenas aceitavam uma madrinha e um padrinho, como eram os casos do Porto (1541) e de Coimbra (1548), e outras toleravam o número de três pais espirituais, como verificamos para Braga (1538), Algarve (1554), Tomar (1555) ou Angra (1560).

Mas o controle não se cingiu apenas aos leigos. As constituições diocesanas da segunda metade do século XV abarcaram questões embaraçosas, como os batizados dos filhos dos clérigos que não davam um bom exemplo ao povo. Pelos vistos, quando os membros do clero batizavam os seus filhos, recorriam a um número considerável de padrinhos e, posteriormente, organizavam banquetes e grandes festividades. Para travar essas atitudes, que podiam dar azo a críticas, o Arcebispo de Braga propôs aos clérigos que os batizassem honestamente ou até encobertamente ${ }^{46}$. Mas o alargamento das recomendações sobre o assunto nas constituições de transição revelou a permanência do problema. Assim sendo, as constituições posteriores decretaram que os seus filhos só fossem acompanhados pelos padrinhos e pela pessoa que os carregasse e, da mesma forma, não fossem batizados na igreja onde exerciam funções. Na falta de uma outra solução, então o sacramento seria realizado sem aparato e sem a presença de alguém ${ }^{47}$.

${ }^{45}$ Constituições synodaes do Bispado de Coimbra (doravante Constituições sinodais de Coimbra). Coimbra: Ioão da Barreyra e Ioã Aluarez, 1548, fl. 5.

46 “Constituições Sinodais de D. Luís Pires, Braga 11 Dez.1477”. in GARCIA Y GARCIA, Antonio (dir.) - Synodicon Hispanum..., cit., pp. 123 e 125.

${ }^{47}$ Constituições Synodaes do Bispado d'Angra: feitas pelo Exmo. e Rvdmo. Sr. Bispo D. Jorge de Santyago e approvadas em Synodo Episcopal celebrado na Sé Cathedral no ano de 1559 (doravante Constituições sinodais de Angra). Lisboa: João Blávio de Colónia, 1560, fl. 4v.; Constituicoens do arcebispado de Lixboa. Lisboa: Germam Galharde, 1537, fl. 3-3v.

Medievalista online № $16 \mid$ Julho - De ze mbro 2014 @ $\mathbb{E M}$ - Instituto de Estudos Medieva is 13 www2.fc sh.unl.pt/ ie $\mathrm{m} / \mathrm{me}$ die va lista 
Todavia as constituições de transição não ficaram por aqui. As novas regras, mais limitativas, foram extensivas a outros assuntos. Os nomes das crianças ficaram circunscritos aos nomes de santos canonizados para que estes, um dia, servissem de seus advogados diante de Deus ${ }^{48}$. Além do mais, esta escolha coibiria os pais de optar por nomes pagãos (gregos, latinos e cartagineses) retomados por influência do Humanismo ${ }^{49}$. E, contrariando alguns manuais de liturgia, prescreveram que a imersão fosse feita em apenas um ato, para não colocar em perigo a vida do recém-nascido, admitindo inclusive a aspersão, que consistia no derramamento da água na cabeça e no rosto. A aspersão, no entanto, apenas seria posta em prática em algumas circunstâncias: quando houvesse insuficiência da água; no caso de perigo de vida da criança; ou quando o ministro se encontrasse fraco ou impedido de realizar a imersão. Em qualquer destas situações, a água deveria tocar na pele e não na roupa ${ }^{50}$. Finalmente, e para saber se algumas destas regras estavam a ser cumpridas, instituiu-se, ainda antes do Concílio de Trento, a obrigatoriedade de registo dos batismos em livro próprio, no qual constariam o dia, mês e ano em que o sacramento se realizou, o nome do neófito, dos pais e dos padrinhos, o local onde residiam e a qualidade ou respetivos ofícios, bem como o nome do sacerdote; e, se houvesse necessidade de ocultar os nomes do pai e da mãe, deveria anotar-se apenas quem o havia mandado batizar e se era ou não legítimo. Do mesmo modo, se o oitavo dia de batismo fosse ultrapassado, por se tratar de enjeitado ou por qualquer outro motivo, dever-se-ia apurar a idade que o bebé teria. Os batizados em caso de necessidade, que abordaremos em seguida, seriam registados depois de receberem o óleo e crisma na igreja ${ }^{51}$.

\section{Batismo de extrema-necessidade e condicional}

48 Constituições sinodais de Coimbra, fl. 3v.; Constituições do Bispado Deuora. Lixboa: Germam Galharde, 1534, fl. 2v.-3.

49 PROSPERI, Adriano -“Battesimo e identità Cristiana nella prima età moderna”. in PROSPERI, Adriano (coord.) - Salvezza delle anime disciplina dei corpi: Un seminario sulla storia del battesimo. Pisa: Edizioni della Normale, 2006, pp. 14-15.

${ }^{50}$ Constituições sinodais de Coimbra, fl. 3; Constituyções synodaes do bispado de Viseu. Coimbra: Ioam Aluares, 1556, fl. 4-4v.

${ }^{51}$ Constituyções da Iurisdiçam ecclesiastica da Villa de Tomar e dos mais lugares que pleno iure pertençem aa ordem d'nosso senhor Iesu Christo. Lisboa: Germão Galharde, 1555, fl. 3.

Medievalista online № 16 | Julho - De zembro 2014 (C) IEM - Instituto de Estudos Me dieva is 14 www2.fc sh.unl.pt/ ie m/me die va lista 
A legislação religiosa não teve apenas em conta o batismo "normal", que se realizava no templo religioso e que requeria uma pia batismal; criou também soluções para situações de risco de vida. Para os partos complicados, desenvolveu o "batismo de extrema-necessidade", já referido nas constituições sinodais do século XIII ${ }^{52}$. Foram, porém, as do século XVI que deram um protagonismo especial às parteiras na sua administração, já que eram elas quem assistia à maioria dos $\operatorname{partos}^{53}$. Independentemente do local onde se encontravam, as parteiras deveriam batizar as crianças por aspersão porque estava em causa a sua salvação, ao que não podia faltar água limpa ${ }^{54}$. Se a criança não conseguisse nascer do ventre da mãe, deveriam batizá-la no primeiro membro que surgisse ${ }^{55}$. No manual litúrgico de Braga, datado de 1562, o batismo de extrema-necessidade é referido como sendo destinado a ser aplicado em casa do bebé, dando liberdade ao ministro para o administrar no momento em que a parturiente tentava dar à luz, aconselhando que derramasse a água sob a forma de cruz num dos membros do bebé que surgisse no imediato ${ }^{56}$. Da mesma forma, e na ausência das parteiras, as constituições sinodais permitiam que o batismo de extrema-necessidade fosse ministrado pelos pais e até por hereges, pagãos e excomungados, desde que soubessem a fórmula batismal: Eu te baptizo em nome do padre e do filho e do spirito sancto. Ámen, não especificando contudo se também poderiam intervir durante o parto $^{57}$.

Se melhorasse de saúde, o recém-nascido deveria ser levado à igreja, passados oito dias, para aí receber o batismo solene. O padre deveria então perguntar como havia sido batizado e, se o que lhe fosse reportado não lhe agradasse, aplicaria o designado batismo condicional, que consistia em dizer no momento em que erguia o bebé da pia

52 "Sínodo de Lisboa celebrado cerca de 1240". in GARCIA Y GARCIA, Antonio (dir.) - Synodicon Hispanum..., cit., p. 287.

${ }^{53}$ Constituições sinodais de Angra, fl. 4.

${ }^{54}$ OLIVEIRA, Ana Maria Tavares da Silva Rodrigues - A criança na sociedade medieval portuguesa: modelos e comportamentos. Universidade Nova de Lisboa: Faculdade de Ciências Sociais e Humanas, 2004, p. 82. (Tese de Doutoramento).

${ }^{55}$ Constituições sinodais de Coimbra, fl. 3.

${ }^{56}$ Manuale secundum Ordine[m] almae Bracare[n]sis Ecclesiae. Bracarae: Antonij de Mariz, 1562, fl. $17 \mathrm{v}$.

${ }^{57}$ Constituições Sinodais do bispado do Porto ordenadas pelo muito Reverendo e magnifico Senhor Dom Baltasar Limpo (doravante Constituições sinodais do Porto). Porto: Vasco Diaz Tanquo de Frexenal, 1541, fl. 3 .

Medievalista online № 16 । Julho - De ze mbro 2014 ๑ $\mathbb{E M}$ - Instituto de Estudos Medie va is 15 www2.fc sh.unl.pt/ie m/me die va lista 
batismal: Si tu baptizatus es, ego non te rebaptizo, sed si tu baptizatus non es, ego baptizo te in nomine Patris et Filii et Spiritus Sancti. Amen ${ }^{58}$. Todavia, não devemos ligar o batismo condicional apenas ao batismo de extrema-necessidade, uma vez que era também aplicado aos enjeitados, mesmo que trouxessem consigo escritos que mencionassem que já haviam sido batizados ${ }^{59}$.

\section{O destino das crianças não batizadas}

Crianças havia que nem a sorte tinham de receber o batismo de extremanecessidade e, muito menos, o batismo condicional porque nasciam mortas, o que se deveria tornar num verdadeiro pesadelo para os progenitores.

Excluídas do Céu por Santo Agostinho, as almas das crianças mortas sem batismo foram encaminhadas para o Limbo das crianças (limbus puerorum) a partir do século XIII ${ }^{60}$. De acordo com Didier Lett, foram vários os fatores que estimularam o surgimento deste local no Além. Nasceu como resultado do apelo dos leigos que ansiavam por alternativas menos angustiantes, como consequência do combate ao movimento herético que rejeitava o poder salvífico do batismo, e como uma resposta mais eficaz à natureza particular do pecado original que pretendia diferenciar-se dos restantes pecados ${ }^{61}$.

Mesmo sendo contestado pelos adeptos da doutrina agostiniana, já que não passava de uma mera hipótese teológica, o limbus puerorum mereceu o reconhecimento de certos escolásticos, em especial de S. Vicente Ferrer, cujos sermões garantiram a sua difusão pela Península Ibérica $^{62}$. Se bem que, presentemente, desconheçamos testemunhos iconográficos do Limbo em Portugal e haja uma falta de referências concretas nas constituições sinodais - contrariamente ao que acontece nas do reino vizinho que o mencionam - estamos convencidos de que não esteve ausente do

\footnotetext{
${ }^{58}$ Bautisterio romão, fl. B4v.

${ }^{59}$ Constituições sinodais do Porto, fl. 4.

${ }^{60}$ LE GOFF, Jacques - The Medieval Imagination. Chicago: University of Chicago Press, 1992, p. 71.

${ }^{61}$ LETT, Didier - L'enfant des miracles: Enfance et société au Moyen Âge (XIIe-XIIIe siècle). Paris: Aubier, 1997, p. 216.

62 RODRÍGUEZ BARRAL, Paulino - La imagen de la justicia divina. La retribución del comportamiento Humano en el más alla en el arte de la Corona de Aragón medieval. Barcelona: Universidade Autónoma de Barcelona, 2003, p. 50. (Tese de Doutoramento).
}

Medievalista online № 16 I Julho - De zembro 2014 (C) $\mathbb{E M}$ - Instituto de Estudos Me dieva is 16 www2.fc sh.unl.pt/ ie m/me die va lista 
pensamento português medieval ${ }^{63}$. Há indícios de que tenha sido subtilmente incluído numa constituição sinodal do século XV quando se faz alusão às crianças penadas ${ }^{64}$. Poder-se-á afirmar que se referia indiretamente às crianças no Limbo porque, segundo José Mattoso, os penados identificavam-se com as almas em trânsito, isto é, que não tinham direito a alcançar um destino definitivo ${ }^{65}$. Emergirá, contudo, mais claramente ao longo do século XVI, citado por várias vezes na literatura religiosa portuguesa ${ }^{66}$. No Cathecismo Pequeno (1504) do bispo de Viseu D. Diogo Ortiz de Vilhegas (c. 14541519), já encontramos a referência ao Limbo dos "mininos" que foram inseridos no grupo das almas que não aguardariam a graça e os merecimentos vindoiros ${ }^{67}$.

Muito embora tenha sido criado para proporcionar um destino menos doloroso às crianças sem batismo, estas não deixavam de estar confinadas a um local votado ao esquecimento, já que não mereciam alcançar a visão de Deus. A solução encontrada na Europa Central para minorar as angústias dos pais passou pelos santuários à répit e no noroeste da Península Ibérica pelo batismo de ponte ${ }^{68}$.

\footnotetext{
${ }^{63}$ Maria do Rosário Bastos demonstra, a partir do livro sinodal de Gonzalo de Alba de 1410, que os cinco lugares destinados às almas dos mortos já se encontravam organizados no reino vizinho. Cit. por BASTOS, Maria do Rosário - "Prescrições sinodais sobre o culto dos mortos nos séculos XIII a XV". in MATTOSO, JOSÉ (dir.) - O Reino dos Mortos na Idade Média Peninsular. Lisboa: Edições Sá da Costa, 1996, p. 113.

64 “Constituições Sinodais de D. Luís Pires, Braga 11 Dez. 1477”. In GARCIA Y GARCIA, Antonio Synodicon Hispanum..., cit., p. 102.

${ }^{65}$ MATtOSO, José - Obras Completas. Vol. 4 - Poderes invisíveis: o imaginário medieval. Rio de Mouro: Círculo de Leitores, 2001, p. 161.

${ }^{66}$ A título de exemplo, foi mencionado nos sermões das «almas do purgatório» (c. 1581-1598) do jesuíta Inácio Martins ou na obra Os Tratados sobre os Quatro Novissimos com lugares comuns dos Padres sobre a mesma matéria (1622), de frei António Rosado.
}

${ }^{67}$ SILVA, Elsa Maria Branco da - O Cathecismo..., cit., p. 215.

${ }^{68}$ Os santuários à répit eram capelas dedicadas à Virgem Maria, santa protetora das crianças, que a partir do século XIV se transformaram em santuários especializados no milagre da ressurreição momentânea. Já o batismo de ponte, narrado ainda nos estudos etnográficos de Leite de Vasconcelos, ocorria à meia-noite numa ponte, implicando o batismo de aspersão sobre o ventre das mulheres ainda antes da gravidez chegar ao seu termo. Cf. PROSPERI, Adriano - Battesimo e identità..., cit., pp. 28-29; MOREL, MarieFrance - "GÉLIS (Jacques) - Les Enfants des Limbes. Mort-nés et parents dans l'Europe chrétienne", Histoire de l'éducation [Em linha], $\mathrm{N}^{\mathrm{o}} 113 \quad$ (2007). URL: http://histoireeducation.revues.org/index1357.html. [consultado a 5 de Janeiro de 2012]; VASCONCELOS, José Leite de - Etnografia Portuguesa. Vol. 4. Lisboa: Imprensa Nacional-Casa da Moeda, 2007, p. 47.

Medievalista online № 16 I Julho - De zembro 2014 (C) $\mathbb{E M}$ - Instituto de Estudos Medieva is 17 www2.fc sh.unl.pt/ie m/me die va lista 


\section{O batismo e o contexto social. Um caso: o batismo real.}

Era incontestável que a natureza do pecado original abarcava a todos e a todos condenava. O diálogo de Santo Agostinho assim o anuía: "E para além disso porque admito que os que nascem, quaisquer que sejam os seus pais, estariam sempre debaixo do domínio do diabo" $" 69$. Em virtude deste pensamento, nem os infantes estavam livres do pior destino no além e, o certo, é que a autoridade agostiniana prevaleceu sobre a autoridade régia chegando inclusive a causar temor às Rainhas, como aconteceu com D. Filipa de Lencastre (1360-1415). Conta o hagiógrafo do infante D. Fernando, mártir de Fez, que a rainha, com febres e fraquezas durante a gravidez, foi aconselhada a tomar um abortivo para não colocar a sua vida em perigo, ao que recusou, para levar a gravidez ao fim e viabilizar o batismo do seu filho ${ }^{70}$.

Assim, e conquanto estivessem subordinados ao primeiro sacramento a fim de obterem a salvação, a verdade é que os príncipes renasciam em Cristo da forma mais faustosa possível, com os melhores objetos disponíveis, quer de prata, quer de ouro, com materiais cuidadosamente selecionados e no espaço que mais lhes convinha ${ }^{71}$. É que, ao contrário do que possamos imaginar, o ritual do batismo era bastante flexível e, tal como os restantes rituais, modificava-se e enriquecia com a introdução de novos elementos que correspondiam à condição social da criança ${ }^{72}$. Ao abrirmos caminho ao estudo do batismo da família real, mais rico em informações a partir do século XV, apercebemo-nos desse particularismo. O objetivo era um: destacar o poder real.

\footnotetext{
69 AGUSTIN, San - "De Nuptiis et Concupiscentia". in Escritos antipelagianos (3\%); trad. em espanhol por Teodoro C. Madrid e Luis Arias Alvarez. Madrid: La Editorial Católica, 1984, p. 245 (tradução da nossa responsabilidade).

${ }^{70}$ Chronica dos feitos, vida, e morte do Iffante sancto Dom Fernando, que morreo em Feez: reuista \& reformada agora de nouo / pelo padre Frey Hieronymo de Ramos da Ordem dos Preegadores: demandado do Serenissimo Cardeal Iffante, \&c. \& a elle dirigida. Em Lisboa: per Antonio Ribeiro, 1577, fl. 2-3.

${ }^{71}$ As constituições de transição privilegiaram a Monarquia ao não restringirem o espaço para a cerimónia do batismo: "E defendemos que nenhum sacerdote baptize criança em casa de algua pessoa, saluo sendo filhos legítimos de reis ou príncipes que segundo direito canonico podem ser baptizados onde seus pais ordenarem". Constituicoens do bispado do Algarue. Lisboa: Germão Galharde, 1554, fl. 2 v.

${ }^{72}$ ALTHOFF, Gerd - "The Variability of Rituals in the Middle Ages". in ALTHOFF, Gerd; FRIED Johannes; GEARY Patrick J. (eds.) - Medieval Concepts of the Past: Ritual, Memory, Historiography. Cambridge: Cambridge University Press, 2003, p. 76.
}

Medievalista online № 16 | Julho - De zembro 2014 @ IEM - Instituto de Estudos Me dieva is 18 www2.fc sh.unl.pt/ie m/me die va lista 
A ostentação da monarquia portuguesa no correr do batismo real exigia acima de tudo o cumprimento de um protocolo sofisticado que incluía por exemplo o uso do pálio, a presença de tochas e uma procissão. Ao que tudo indica, este protocolo resultou da influência dos costumes da corte inglesa, que chegou a Portugal através da obra Liber Regie Capelle (c. 1449), durante a regência do infante D. Pedro (1438-1449) ${ }^{73}$.

Era a capela real que organizava a cerimónia, tanto no exterior como no interior do templo religioso ${ }^{74}$. Detenhamo-nos em primeiro lugar no espaço exterior, onde ocorria um cortejo que, narrado por Garcia de Resende na crónica de D. João II, seguia sempre uma ordem hierárquica ${ }^{75}$. Os cronistas que o sucederam relataram da mesma forma a procissão real que, pelos vistos, obedecia a uma mesma regra: na dianteira da procissão seguiam os músicos, os funcionários da Corte (oficiais de cerimónias, da Mesa dos Reis, da Casa Real ou da Fazenda), e a nobreza que carregava tochas apagadas que, no regresso já vinham acesas. De seguida, prosseguia a fidalguia mais importante que transportava as insígnias: círio, maçapão, gomil, bacio das ofertas, saleiro e toalha. Por fim, ia o baptizando ao colo de uma figura masculina, que podia ser da família ou alguém íntimo e de confiança dos monarcas ${ }^{76}$; ambos eram acompanhados pelos padrinhos e abrigados por um pálio bastante adornado, cujas quatro varas eram seguras pelos grandes do reino. A hierarquia implícita no cortejo batismal

${ }^{73}$ GOMES, Rita Costa - The Making of Court Society: Kings and Nobles in Late Medieval Portugal. Cambridge: Cambridge University Press, 2003, pp. 367-368; SILVA, Maria Manuela Santos - "Práticas religiosas e hábitos culturais inovadores na corte dos reis de Portugal (1387-1415)". in COLÓQUIO PODER ESPIRITUAL/ PODER TEMPORAL, Lisboa, 2009 - As relações Igreja/ Estado no tempo da monarquia (1179 - 1909): actas. Lisboa: Academia Portuguesa da História, 2009, pp. 195-212.

74 CURTO, Diogo Ramada - "A capela real: um espaço de conflitos (séculos XVI a XVIII)". in COLÓQUIO ESPIRITUALIDADE E CORTE EM PORTUGAL, 5, Porto - Espiritualidade e corte em Portugal : séculos XVI a XVIII: actas. Porto: Inst.Cult.Portuguesa, 1993, p. 149.

${ }^{75}$ Choronica que tracta da vida e grandissimas virtudes e bondades, magnanimo esforço, excellentes costumes \& manhas \& claros feytos do christianissimo Dom Ioão ho segundo deste nome \& dos reys de Portugal ho decimo tercio de gloriosa memoria, começado de seu nascimento \& toda sua vida ate hora de sua morte ; com outras obras que adiante se seguem / feyta por Garcia de Rêsende. Em Lisboa: em casa de Simão Lopez, 1596, fl. A1-1v.

${ }^{76}$ No manual litúrgico de D. Maria (1538-1577), a infanta esclarece que o batizante deveria ser levado ao colo de um infante mais velho e que, na sua ausência, o levaria um grande nobre; Acrescenta também que um moço fidalgo segurava a ponta da mantilha do bebé durante o correr da procissão. Ver. CARDOSO, José Maria Pedrosa - Cerimonial da Capela Real: Um manual litúrgico de D. Maria de Portugal (15381577), Princesa de Parma. Lisboa: Imprensa Nacional-Casa da Moeda, 2008, p. 126.

Medievalista online № 16 | Julho - De zembro 2014 (C) $\mathbb{E M}$ - Instituto de Estudos Me dieva is 19 www2.fc sh.unl.pt/ ie $\mathrm{m} / \mathrm{me}$ die va lista 
refletia/representava visualmente a hierarquia social, em cujo topo se encontravam os membros da família real.

Apesar das Crónicas não relatarem a cerimónia no interior da igreja, através dos objetos empregues no cerimonial do batismo ficamos com uma ideia de como poderia ocorrer. Sabemos, por exemplo, que, tal como as crianças das restantes camadas sociais, os infantes recebiam os exorcismos para afugentar o diabo no adro da igreja, nos quais o saleiro desempenhava um papel importante. Da mesma forma, sabemos que os príncipes recebiam a unção dos santos óleos no peito e nas omoplatas, porque o maçapão deveria ter o mesmo propósito que o mazapán teria no batismo real espanhol: auxiliar o sacerdote a limpar os dedos após a colocação dos santos óleos no batizando ${ }^{77}$.

Decorrida a fase da unção, os infantes não eram batizados numa pia batismal de pedra, mas numa pia amovível, descrita, no manual litúrgico de D. Maria (1538-1577) como uma "bacia de prata muito grande" Tudor também se serviu de uma pia de prata para o efeito ${ }^{79}$. O batismo de imersão era o que vigorava na corte portuguesa, ilação esta que podemos retirar do relato de Tomé Pinheiro da Veiga (1570-1656) aquando da sua visita a Valladolid. Ao assistir ao batismo do infante Filipe III, que ocorreu a 29 de Maio de 1605, o português notou que havia diferenças entre o batismo real português e o batismo real espanhol, comparações que só poderiam ter sido feitas tendo em mente o que tinha sido usual na Dinastia de Avis, porque, no tempo em que escreveu a obra Fastigimia, Portugal encontrava-se sob a alçada da Dinastia de Habsburgo. Eis as suas deduções: "Concluo com o batismo com vos dizer que nelles se tem em muytos diferente forma do que se custuma em Portugal, por que, $[\ldots]$ não o metem na agua, senão com huma concha lha deitam na cabeça". Finda a imersão, as diferenças continuavam na terceira fase do ritual; colocava-se uma

\footnotetext{
77 A denominação de maçapão foi por vezes substituída por rosca ou fogaça. Mesmo que para um período tardio, podemos também tirar essa ilação a partir do Ritual Romano de 1614; este manual aconselhava que o sacerdote limpasse o seu dedo polegar com um pouco de pão. Para o mazapán ver a tese de Margarita Garcia Barranco - Antropología histórica de una élite de poder: las reinas de España. Granada: Editorial de la Universidad de Granada, 2007, p. 291 (Tese de Doutoramento).

${ }^{78}$ A bacia de prata continuou a ser mencionada e empregue pela Dinastia de Bragança. No batismo de D. Afonso VI e do seu irmão D. Pedro II, por exemplo, foi colocada na capela-mor. CARDOSO, José Maria Pedrosa - Cerimonial da Capela Real..., cit., p. 126; ANTT, Colecção de S. Vicente, vol. 20, fl. 54: "se hade por a baçia de prata em que se hade fazer/ o Bautismo, E esta hade estar cuberta com sua toalha”.

${ }^{79}$ ORME, Nicholas - Medieval Children. London: Yale University Press, 2001, p. 33.
} 
estola de linho na cabeça do infante português, enquanto que ao infante espanhol se colocava um véu que, segundo o autor, correspondia à veste branca que os catecúmenos utilizavam nos primeiros tempos da Igreja Cristã ${ }^{80}$.

A mãe do infante encontra-se ausente nos relatos das Crónicas porque, tal como as restantes mães de qualquer grupo social, não podia comparecer na igreja após o parto. Impura por dar à luz, a parturiente estava excluída do templo religioso por quarenta $\operatorname{dias}^{81}$.

\section{Epílogo}

O pensamento dos vários Padres da Igreja, principalmente o de Santo Agostinho, esteve, como vimos, na promoção do batismo infantil. Mas o êxito do ritual não se deveu apenas às suas reflexões. Foi graças aos contínuos esforços da Igreja que o batismo das crianças deveu o seu êxito. Recordemos a diversidade litúrgica daí decorrente. Cedo os teólogos perceberam que apenas com uma abertura conseguiriam a atenção das comunidades cristãs e, por isso, permitiram que a liturgia romana absorvesse certas expressões locais, familiares portanto, aos que pretendiam aliciar. No caso português, identificamos esta tolerância através dos manuais litúrgicos de Braga, Coimbra e Évora que, apesar de seguirem um corpo comum - o ritual romano buscaram no ritual galicano toda a sua riqueza gestual e simbólica. Com ou sem divergências, o essencial era que o batismo não perdesse a sua força mágica e que, no decorrer das suas três fases, atuasse corretamente sobre a alma da criança para que não caísse em perdição. Por isso, numa primeira etapa, fora da igreja, exorcizavam-na para a desprender dos laços demoníacos; num segundo momento, junto da pia batismal, banhavam-na na água lustral para a limpar da mácula herdada de Adão e Eva e, na terceira e última fase, acolhiam-na como filha de Deus.

Mas, à medida que foram aumentando os abusos por parte do clero e foram emergindo vozes contra o poder salvífico do batismo, a Igreja Católica teve necessidade de intervir no sentido de controlar e unificar o sacramento. As constituições diocesanas a partir dos finais da Idade Média espelham essa mesma mudança e inquietação.

80 VEIGA, Thomé Pinheiro da - Fastigimia. Lisboa: Imprensa Nacional-Casa da Moeda, 1988, p. 83; OLIVEIRA, António de - D. Filipe III. Rio de Mouro: Círculo de Leitores, 2005, p. 29.

${ }^{81}$ BARDSLEY, Sandy - Women's Roles..., cit., p. 47.

Medievalista online № 16 । Julho - De ze mbro 2014 @ EMM - Instituto de Estudos Medieva is 21 www2.fc sh.unl.pt/ie m/me die va lista 
Recordemos que o ritual do batismo passou a ser efetuado até ao oitavo dia de vida do bebé, impondo-se à seleção dos padrinhos critérios mais claros quanto à sua idade, percurso religioso, condição matrimonial e integridade física; e nem os bebés que nasciam frágeis eram perdoados. Batizados à pressa, eram aspergidos com água pelas parteiras ou mesmo pelos próprios progenitores.

Se todas as crianças nasciam com o pecado original, independentemente da condição social a que pertenciam, também os príncipes e infantes portugueses deveriam lavar as suas almas com o batismo. Paralelamente ao papel salvífico e de inclusão religiosa, a dinastia de Avis fez também da celebração deste sacramento uma ocasião de exaltação do poder real que se manifestava particularmente na procissão.

Em suma, a afirmação da imperiosa necessidade do batismo para a salvação feita ao longo da Idade Média e a sua geral antecipação para os primeiros dias de vida, a crescente vigilância eclesiástica sobre a sua celebração e a obrigatoriedade do seu registo em livros próprios levaram a que, atingida a época moderna, a sua celebração se generalizasse. Porta para a admissão na Igreja e para a salvação eterna, o batismo foi também um ato de integração e, na sua própria execução, um espelho das hierarquias que configuravam o corpo social.

\section{REFERÊNCIAS BIBLIOGRÁFICAS}

\section{Fontes impressas}

AGUSTIN, San -“De Nuptiis et Concupiscentia”.in Escritos antipelagianos (3 $3^{\circ}$; trad. em espanhol por Teodoro C. Madrid e Luis Arias Alvarez. Madrid: La Editorial Católica, 1984, pp. 301-388.

ÁLVARES, Fr. João, Chronica dos feitos, vida, e morte do Iffante sancto Dom Fernando, que morreo em Feez: reuista \& reformada agora de nouo / pelo padre Frey Hieronymo de Ramos da Ordem dos Preegadores: demandado do Serenissimo Cardeal Iffante, \&c. \& a elle dirigida. Em Lisboa: per Antonio Ribeiro, 1577.

ANDRADE, Francisco de - Cronica do mvyto alto e mvito poderoso rey destes reynos de Portugal dom Ioão o III deste nome. Lisboa: Jorge Rodriguez, 1613.

Baptisteriu[m] seu manuale Elborense noviter eme(n]datus. Hispali: per Jacobum Cromberger, 1528. 
Bautisteiro romão cõ algu[m]as outras cousas necessarias aos curas e capellães e cõ as rubricas em lingoage[m] conforme ao mais geral uso de MDLX. Lisboa: Germão Galharde, 1560.

BRAGANÇA, Joaquim O. - Missal de Mateus: manuscrito 1000 da Biblioteca Pública e Arquivo Distrital de Braga. Lisboa: Fundação Calouste Gulbenkian, 1975.

CARDOSO, José Maria Pedrosa - Cerimonial da Capela Real: Um manual litúrgico de D. Maria de Portugal (1538-1577), Princesa de Parma. Lisboa: Imprensa NacionalCasa da Moeda, 2008.

Constituyções da Iurisdiçam ecclesiastica da Villa de Tomar e dos mais lugares que pleno iure pertençem aa ordem d'nosso senhor Iesu Christo. Lisboa: Germão Galharde, 1555.

Constituições do arcebispado de Braga. Lisboa: Germã Galharde, 1538.

Constituicoens do arcebispado de Lixboa. Lisboa: Germam Galharde, 1537.

Constituições do Bispado Deuora. Lixboa: Germam Galharde, 1534.

“Constituições Sinodais de D. Frei Telo, Braga, 1285". in GARCIA Y GARCIA, Antonio (dir.) - Synodicon Hispanum: Vol.2, Portugal. Madrid: Editorial Católica, 1982, pp. 26-29.

"Constituições Sinodais de D. Luís Pires, Braga 11 Dez.1477”. in GARCIA Y GARCIA, Antonio (dir.) - Synodicon Hispanum: Vol.2, Portugal. Madrid: Editorial Católica, 1982, pp. 73-137.

Constituições Synodaes do Bispado d'Angra: feitas pelo Exmo. e Rvdmo. Sr. Bispo D. Jorge de Santyago e approvadas em Synodo Episcopal celebrado na Sé Cathedral no ano de 1559. Lisboa: João Blávio de Colónia, 1560.

Constituições synodaes do Bispado de Coimbra. Coimbra: Ioão da Barreyra e Ioã Aluarez, 1548.

Constituyções synodaes do bispado de Viseu. Coimbra: Ioam Aluares, 1556.

Constituições Sinodais do bispado do Porto ordenadas pelo muito Reverendo e magnifico Senhor Dom Baltasar Limpo. Porto: Vasco Diaz Tanquo de Frexenal, 1541.

Manuale secundu[m] consuetudinem alme Colymbrieñ [sic] Ecclesie. Lixboneñ ciuitate: Nicolaum Gazini, 1518.

Manuale secundum Ordine[m] almae Bracare[n]sis Ecclesiae. Bracarae: Antonij de Mariz, 1562.

Medievalista online № 16 I Julho - De ze mbro 2014 (C) EM - Instituto de Estudos Me die va is 23 www2.fc sh.unl.pt/ ie $\mathrm{m} / \mathrm{me}$ die va lista 
Neste breue manual se [con]ten cousas muito necessarias e p[ro]ueitosas a todo sacerdote q[ue] ha de administrar e dar os sacrame[n]tos...E assi som muitas missas deuotissimas e p[ro]ueitosas p[e]ra ha saude dalma e do corpo. as quaes nu[n]ca foro[m] postas em nenhu[m] missal ne[m] manual de Braga. Impressus in antiquissima bracharensis civitate: [s.n.], 1517.

RESENDE, Garcia de - Choronica que tracta da vida e grandissimas virtudes $e$ bondades, magnanimo esforço, excellentes costumes \& manhas \& claros feytos do christianissimo Dom Ioão ho segundo deste nome \& dos reys de Portugal ho decimo tercio de gloriosa memoria, começado de seu nascimento \& toda sua vida ate hora de sua morte ; com outras obras que adiante se seguem. Em Lisboa: em casa de Simão Lopez, 1596.

SILVA, Elsa Maria Branco da - O Cathecismo Pequeno de D. Diogo Ortiz, Bispo de Viseu. Lisboa: Colibri, 2001.

"Sínodo de Lisboa celebrado cerca de 1240". in GARCIA Y GARCIA, Antonio (dir.) Synodicon Hispanum: Vol.2, Portugal. Madrid: Editorial Católica, 1982, pp. 285-297.

VEIGA, Thomé Pinheiro da - Fastigimia. Lisboa: Imprensa Nacional-Casa da Moeda, 1988

\section{Estudos}

ALTHOFF, Gerd - "The Variability of Rituals in the Middle Ages". in ALTHOFF, Gerd; FRIED Johannes; GEARY Patrick J. (eds.) - Medieval Concepts of the Past: Ritual, Memory, Historiography. Cambridge: Cambridge University Press, 2003, pp. 71-88.

BARDSLEY, Sandy - Women's Roles in the Middle Ages. Portsmouth: Greenwood Press, 2007.

BAREILLE, G. - "Baptême”. in VACANT, A.; E. MANGENOT; É. AMANN, (eds.) Dictionnaire de Théologie Catholique contenant l'exposé des doctrines de la théologie catholique leurs preuves et leur histoire: Tome Deuxième. Paris: Librairie Letouzey et Ané, 1932, pp. 167-219.

BARRANCO, Margarita Garcia - Antropología histórica de una élite de poder: las reinas de España. Granada: Editorial de la Universidad de Granada, 2007. (Tese de Doutoramento).

BASTOS, Maria do Rosário - "Prescrições sinodais sobre o culto dos mortos nos séculos XIII a XV". in MATTOSO, José (dir.) - O Reino dos Mortos na Idade Média Peninsular. Lisboa: Edições Sá da Costa, 1996, pp. 109-124. 
BRAGANÇA, Joaquim de Oliveira - "Influência religiosa da França no Portugal Medievo”. Didaskalia. Lisboa. ISSN 0253-1674. 3:1 (1973), pp. 133-156.

BRAGANÇA, Joaquim O. - “A Liturgia de Braga: Missal - Ritual - Pontificial”. in CONGRESSO INTERNACIONAL DO IX CENTENÁRIO DA DEDICAÇÃO DA SÉ DE BRAGA, 3, Braga, 1990 - Teologia do Templo e Liturgia Bracarense: actas. Braga: Universidade Católica Portuguesa, 1990, pp. 117-126.

CARVALHO, Joaquim Félix de - "A Liturgia em Braga". Didaskalia. Lisboa ISSN 0253-1674. 37:2 (2007), pp. 139-184.

BRAGANÇA, Joaquim O. - "Le symbolisme des rites baptismaux au Moyen Age: les rites d'admission au catéchuménat”. Didaskalia. Lisboa. ISSN 0253-1674. 3:1 (1973), pp. 37-56.

CURTO, Diogo Ramada - "A capela real: um espaço de conflitos (séculos XVI a XVIII)". in COLÓQUIO ESPIRITUALIDADE E CORTE EM PORTUGAL, 5, Porto Espiritualidade e corte em Portugal: séculos XVI a XVIII: actas. Porto: Inst.Cult.Portuguesa, 1993, pp. 143-154.

DELUMEAU, Jean - Nascimento e Afirmação da Reforma. São Paulo: Livraria Pioneira Editora, 1989.

FERGUSON, Everett - Baptism in the Early Church: History, Theology, and Liturgy in the First Five Centuries. Michigan: Wm. B. Eerdmans Publishing, 2009.

GENNEP, Arnold Van - Os ritos de passagem. Petropolis: Vozes, 1978.

GOMES, Rita Costa - The Making of Court Society: Kings and Nobles in Late Medieval Portugal. Cambridge: Cambridge University Press, 2003.

GOMES, Saul António - "A religião dos clérigos: vivências espirituais, elaboração doutrinal e transmissão cultural". in AZEVEDO, Carlos Moreira (dir.) - História Religiosa de Portugal. Vol. 1: Formação e Limites da Cristandade. Rio de Mouro: Círculo de Leitores, 2000, pp. 339-421.

LE GOFF, Jacques - La civilisation de L'Occident Médiéval. Paris: Arthaud, 1977.

LE GOFF, Jacques - The Medieval Imagination. Chicago: University of Chicago Press, 1992.

LETT, Didier - L'enfant des miracles: Enfance et société au Moyen Âge (XIIe-XIIIe siècle). Paris: Aubier, 1997.

LOPEZ MARTINEZ, Nicolas - "Notas sobre la lucha contra el diablo mediante los sacramentos". in IV SIMPÓSIO INTERNACIONAL DE TEOLOGÍA DE LA UNIVERSIDAD DE NAVARRA, Pamplona, 1983 - Sacramentalidad de la Iglesia y

Medievalista online № 16 । Julho - De ze mbro 2014 @ $\mathbb{E M}$ - Instituto de Estudos Me die va is 25 www2.fc sh.unl.pt/ie m/me die va lista 
Sacramentos: actas. Pamplona: Servicio de Publicaciones de la Universidad de Navarra, 1983, pp. 805-817.

MARQUES, João Francisco - "A palavra e o livro". in AZEVEDO, Carlos Moreira (dir.) - História Religiosa de Portugal. Volume 2: Humanismo e Reformas. Rio de Mouro: Círculo de Leitores, 2000, pp. 377-447.

MATtOSO, José - Obras Completas. Vol. 4 - Poderes invisíveis: o imaginário medieval. Rio de Mouro: Círculo de Leitores, 2001.

MUIR, Edward - Fiesta y rito en la Europa Moderna. Madrid: Editorial Complutense, 2001.

OLIVEIRA, Ana Maria Tavares da Silva Rodrigues - A criança na sociedade medieval portuguesa: modelos e comportamentos. Universidade Nova de Lisboa: Faculdade de Ciências Sociais e Humanas, 2004. (Tese de Doutoramento).

OLIVEIRA, António de - D. Filipe III. Rio de Mouro: Círculo de Leitores, 2005.

ORME, Nicholas - Medieval Children. London: Yale University Press, 2001.

PAIVA, José Pedro - “Constituições Diocesanas”. in AZEVEDO, Carlos Moreira (dir.) - Dicionário de História Religiosa de Portugal: C-I. Rio de Mouro: Círculo de Leitores, 2000, pp. 9-15.

PEIXOTO, João da Silva - "Liturgia". in AZEVEDO, Carlos Moreira (dir.) Dicionário de História Religiosa de Portugal: J-P. Rio de Mouro: Círculo de Leitores, 2001, pp. 138-145.

PEIXOTO, João da Silva - "Rito". in AZEVEDO, Carlos Moreira (dir.) - Dicionário de História Religiosa de Portugal: P-V. Rio de Mouro: Círculo de Leitores, 2001, pp. 131135.

PROSPERI, Adriano -“Battesimo e identità Cristiana nella prima età moderna”. in PROSPERI, Adriano (coord.) - Salvezza delle anime disciplina dei corpi: Un seminario sulla storia del battesimo. Pisa: Edizioni della Normale, 2006, pp. 1-65.

RODRÍGUEZ BARRAL, Paulino - La imagen de la justicia divina. La retribución del comportamiento Humano en el más alla en el arte de la Corona de Aragón medieval. Barcelona: Universidade Autónoma de Barcelona, 2003. (Tese de Doutoramento).

ROUCHE, Michel - "O corpo e o coração". in ARIÈS, Philippe; DUBY, Georges História da Vida Privada: Da Europa Feudal ao Renascimento. Porto: Edições Afrontamento, 1990, pp. 437-467.

RUBELLIN, Michel - "Baptême". in VAUCHEZ, André (dir.) - Dictionnaire Encyclopédique du Moyen Âge: Tome I. Paris: Éditions du Cherf, 1997, pp. 171-172.

Medievalista online № $16 \mid$ Julho - De ze mbro 2014 @ $\mathbb{E M}$ - Instituto de Estudos Medieva is 26 www2.fc sh.unl.pt/ie $\mathrm{m} / \mathrm{me}$ die va lista 
SCHLEIF, Corine - "Men on the Right - Women on the Left: (A)symetrical Spaces and Gendered Places". in RAGUIN, Virginia C.; STANBURY, Sarah (eds.) - Women's Space. Patronage, Place, and Gender in the Medieval Church. Albany: State University of New York Press, 2005, pp. 207-249.

SILVA, Elsa Maria Branco da - O Cathecismo Pequeno de D. Diogo Ortiz: Bispo de Viseu. Lisboa: Colibri, 2001.

SILVA, Maria Manuela Santos - "Práticas religiosas e hábitos culturais inovadores na corte dos reis de Portugal (1387 - 1415)". in COLÓQUIO PODER ESPIRITUAL/ PODER TEMPORAL, Lisboa, 2009 - As relações Igrejal Estado no tempo da monarquia (1179 - 1909): actas. Lisboa: Academia Portuguesa da História, 2009, pp. 191-212.

SOARES, António Franquelim Sampaio Neiva - "Os Concílios Suevos (561 e 571)". in KOLLER, Erwin; LAITENBERGER, Hugo (ed.) - Suevos -Swaben: Das Konigreich der Sueben auf der Iberischen Halbinsel (411-585). Tübingen: Gunter Narr Verlag, 1998, pp. 63-79.

WALSH, Liam G. - Sacraments of Initiation: A Theology of Right, Word and Rite. Chicago: Hillenbrand Books, 2011.

\section{Referências eletrónicas:}

MOREL, Marie-France - "GÉLIS (Jacques) - Les Enfants des Limbes. Mort-nés et parents dans l'Europe chrétienne”, Histoire de l'éducation [Em linha], No 113 (2007). URL: http://histoire-education.revues.org/index1357.html. [consultado a 5 de Janeiro de 2012].

\section{COMO CITAR ESTE ARTIGO}

\section{Referência electrónica:}

ALMEIDA, Francisca Pires de - "O ritual do batismo em Portugal na Baixa Idade Média e nos inícios do século XVI".

Medievalista [Em linha]. №16 (Julho - Dezembro 2014). [Consultado dd.mm.aaaa]. Disponível em http://www2.fcsh.unl.pt/iem/medievalista/MEDIEVALISTA16। ISSN 1646-740X. 
0 ritual do batismo em Portugal na Baixa Idade Média e nos inícios do século XVI • Francisca Pires de Almeida

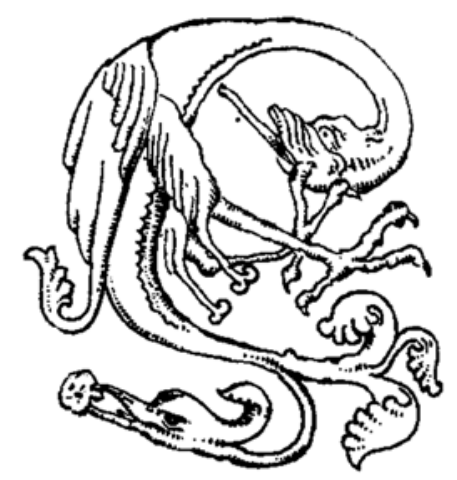

Medievalista online № 16 । Julho - De ze mbro 2014 ๑ $\mathbb{E M}$ - Instituto de Estudos Medieva is 28 www2.fc sh.unl.pt/ie m/me die va lista 